\title{
Lachancea dasiensis sp. nov., an ascosporogenous yeast isolated from soil and leaves in Taiwan
}

\author{
Ching-Fu Lee, Cheng-Hsu Yao, Yi-Ru Liu, Chin-Wen Hsieh \\ and Shuh-Sen Young \\ Department of Applied Science, National Hsinchu University of Education, 521 Nanda Road, \\ Hsinchu 300, Taiwan, ROC
}

Correspondence

Ching-Fu Lee

leecf@mail.nhcue.edu.tw
The species Zygosaccharomyces cidri, Zygosaccharomyces fermentati, Kluyveromyces thermotolerans, Kluyveromyces waltii and Saccharomyces kluyveri were clustered into an independent clade on the basis on combined analysis of multiple gene sequences (Kurtzman, 2003; Kurtzman \& Robnett, 2003), indicating that they are closely related to each other, but to differing extents. A new genus, Lachancea, was proposed to accommodate these five species, and Lachancea thermotolerans was assigned as the type species (Kurtzman, 2003). Since the genus was described, only one further species has been reported, Lachancea meyersii (Fell et al., 2004). The genus is characterized by the fermentation of at least one other sugar in addition to glucose, the production of one to four spherical ascospores after conjugation and the inability to assimilate nitrate.

Species of the genus Lachancea are cosmopolitan and inhabit many niches, including soil, plants, animals and processed foods or beverages (Kurtzman, 1998; VaughanMartini \& Martini, 1998; Lachance, 1998; Fell et al., 2004; Barnett et al., 2000). The type strains of the six species were isolated from different habitats, such as processed foods or

Abbreviations: ITS, internal transcribed spacer; LSU, large subunit; SSU, small subunit.

The GenBank/EMBL/DDBJ accession numbers for the sequences of the D1/D2 domain of the LSU rRNA genes, ITS regions and SSU rRNA genes of strains SC5L02 ${ }^{\top}$, SC6L01 and ES12S06 are respectively EU523636, EU547812 and FJ153149 (D1/D2), FJ153187, FJ153188 and FJ153189 (ITS) and FJ153104, FJ153105 and FJ153106 (SSU). beverages (Legakis, 1961; Naganishi, 1928; Filipov, 1932), holly exudates (Kodama \& Kyono, 1974), Drosophila pinicola (Phaff \& Knapp, 1956) and mangrove habitats (Fell et al., 2004). During a survey of yeast diversity in soil and leaves in Taiwan, three novel yeast strains were isolated; these strains share identical sequences of the D1/ D2 domain of the large-subunit (LSU) rRNA gene, the internal transcribed spacer (ITS) region and the smallsubunit (SSU) rRNA gene and similar physiological characteristics, indicating that they are conspecific. The present paper proposes a novel species to accommodate these three strains, which are closely related to Lachancea waltii and Lachancea thermotolerans.

Strains SC5L02 ${ }^{\mathrm{T}}$ and SC6L01 were isolated from leaves of the fern Angiopteris lygodiifolia Rosenst. and the palm Arenga engleri Beccari, respectively, in Dasi, Taoyuan, in 2006, while strain ES12S06 was isolated from a forest soil sample that was collected in Sinyi, Nantou, in 2007. Isolation of these strains was achieved by the method described by Lee et al. (2008). The yeasts were grown on YM agar at $24{ }^{\circ} \mathrm{C}$ for 3 days, followed by preservation in the freezer at $-70{ }^{\circ} \mathrm{C}$ and/or on $\mathrm{YM}$ agar at $4{ }^{\circ} \mathrm{C}$. The morphological, physiological and biochemical characteristics of the strains were determined by the methods described by Yarrow (1998). Strains used for examination of ascospores were incubated on McClary's acetate agar (Yarrow, 1998) for 28 days at $18{ }^{\circ} \mathrm{C}$.

The D1/D2 domain of the LSU rRNA gene, the SSU rRNA gene and ITS fragments of strains SC5L02, SC6L01 and ES12S06 were amplified using primers NL1 and NL4 
(Kurtzman \& Robnett, 1998), P1 and NS8 (Suzuki \& Nakase, 2002) and ITS1 and ITS4 (White et al., 1990), respectively, with a Peltier thermal cycler (PTC-200; M) Research) from genomic DNA extracted from yeast cells using a Biokit Genome DNA Extraction kit (Biokit Co.). Successful amplification was confirmed by agarose gel electrophoresis. Sequencing of the fragments was performed by using an automated DNA sequencer (Applied Biosystems 3730 DNA Analysis System). Both strands were sequenced, and the reactions were carried out using a Dye Terminator cycle sequencing kit (Applied Biosystems). The sequences were initially aligned using the multiple alignment program CLUSTAL_X 1.83 (Thompson et al., 1997). A phylogenetic tree was constructed using the neighbour-joining method with the MEGA version 4.0 software package (Kumar et al., 2004). Kluyveromyces marxianus CBS $834^{\mathrm{T}}$ was used as an outgroup. Bootstrap analysis was performed from 1000 bootstrap replications (Felsenstein, 1985).

To examine the electrophoretic karyotypes of the yeasts by PFGE, agarose plugs containing intact chromosomal DNA were prepared using the methods of Carle \& Olson (1985) modified as follows. The examined strains were grown on YM agar slants at $25{ }^{\circ} \mathrm{C}$ for $24 \mathrm{~h}$. The cells were then harvested and washed twice with 0.05 M EDTA (pH 7.5) and used to prepare intact yeast chromosomal DNA for PFGE. The washed cell pellets (about $150 \mathrm{mg}$ ) were resuspended in $300 \mu \mathrm{l}$ SCE buffer [ $1 \mathrm{M}$ sorbitol, $0.1 \mathrm{M}$ trisodium citrate ( $\mathrm{pH}$ 5.8) and $0.02 \mathrm{M}$ EDTA ( $\mathrm{pH}$ 7.5)] and mixed with $40 \mu$ lyticase (Sigma) solution (1000 U $\mathrm{ml}^{-1}$ in SCE). After the mixture was incubated at $37{ }^{\circ} \mathrm{C}$ for $30 \mathrm{~min}$, it was mixed with $1 \mathrm{ml} 1.2 \%$ molten agarose (Amresco) in $125 \mathrm{mM}$ EDTA (pH 7.5). The suspension was pipetted into moulds and allowed to solidify at $4{ }^{\circ} \mathrm{C}$ for $15 \mathrm{~min}$, and the solidified plugs were then transferred into $2 \mathrm{ml}$ LET buffer (0.45 M EDTA, pH 8.0, $10 \mathrm{mM}$ Tris/ $\mathrm{HCl}, \mathrm{pH} 8.0,7.5 \%$ 2-mercaptoethanol) and incubated overnight at $37{ }^{\circ} \mathrm{C}$. After being washed in $50 \mathrm{mM}$ EDTA ( $\mathrm{pH} 8.0$ ), the plugs were incubated in $2 \mathrm{ml}$ LEP solution [0.45 M EDTA, pH 8.0, $1 \% \mathrm{~N}$-lauroylsarcosine, $10 \mathrm{mM}$ Tris/HCl, $\mathrm{pH}$ 8.0, $1 \mathrm{mg}$ proteinase $\mathrm{K} \mathrm{ml}^{-1}$ (Merck)] and incubated at $50{ }^{\circ} \mathrm{C}$ for $24 \mathrm{~h}$. The immersion solution was then decanted and the plugs were washed with three changes of $50 \mathrm{mM}$ EDTA at $\mathrm{pH} 8.0$ over a $24 \mathrm{~h}$ period at $50{ }^{\circ} \mathrm{C}$. The washed agarose plugs were stored in $50 \mathrm{mM}$ EDTA (pH 8.0) at $4{ }^{\circ} \mathrm{C}$. Agarose blocks were cut to fit the wells of a $1 \%$ agarose gel (Amresco) and the plug pieces were inserted and sealed in place with $0.8 \%$ agarose. Gels were equilibrated in $0.5 \times$ TBE ( $45 \mathrm{mM}$ Tris/borate, $1 \mathrm{mM}$ EDTA, $\mathrm{pH}$ 8.0) for $1 \mathrm{~h}$ before electrophoresis. Chromosomal DNA bands were separated on $1.0 \%$ agarose gel in $0.5 \times$ TBE buffer in a rotating-field electrophoresis apparatus (Rotaphor 6.0; Biometra). The electrophoresis program was completed in three steps with a total run time of $96 \mathrm{~h}$ : step 1, field switch time of 90 $120 \mathrm{~s}$ for $8 \mathrm{~h}$ at $120 \mathrm{~V}$; step $2,120-360 \mathrm{~s}$ for $28 \mathrm{~h}$ at $120 \mathrm{~V}$; step 3, 360-1200 s for $60 \mathrm{~h}$ at $60 \mathrm{~V}$. The temperature of the running buffer was maintained at $14{ }^{\circ} \mathrm{C}$ throughout the electrophoresis. After electrophoresis, the gels were stained with $0.5 \mu \mathrm{g}$ ethidium bromide $\mathrm{ml}^{-1}$ for $30 \mathrm{~min}$ and destained with tap water for $30 \mathrm{~min}$ and then photographed under UV illumination. Intact chromosomal DNAs of Saccharomyces cerevisiae YPH 80 purchased from Biometra were used as DNA markers.

\section{Sequence comparison}

Reference sequences used in this paper were retrieved from GenBank under the accession numbers indicated in Fig. 1. Strains SC5L02 ${ }^{\mathrm{T}}$, SC6L01 and ES12S06 were found to share identical sequences in the D1/D2 domain of the LSU rRNA gene, the ITS and the SSU rRNA gene, indicating that these strains are conspecific. In the neighbour-joining phylogenetic tree based on the D1/D2 domains of the LSU rRNA gene (Fig. 1), the three strains clustered with L. thermotolerans and $L$. waltii, confirming that the novel species is a member of Lachancea. The three strains differed from their phylogenetically closest relatives, the type strains of $L$. thermotolerans and $L$. waltii, by 9 and 11 nucleotide substitutions in the D1/D2 domains of the LSU rRNA gene (Fig. 1), 26 in the ITS region and 8 and 9 in the SSU rRNA gene, respectively. These results clearly indicate that these strains are representatives of a novel species of Lachancea.

\section{Electrophoretic karyotyping}

Previous studies have shown that all species of Lachancea appear to have an identical number of chromosomes (eight) and they show species-specific patterns of electrophoretic karyotypes according to the range of chromosome sizes (Naumova et al., 2007). In the present paper, only seven chromosomal DNA bands were resolved for strains SC6L02 and ES12S06 under the conditions described above; the band with a stronger relative intensity may correspond to a doublet (Fig. 2, lanes 4-6). Eight chromosomes were assumed to be present in these strains. Strains SC5L02 ${ }^{\mathrm{T}}$, SC6L01 and ES12S06 were found to be quite similar in their electrophoretic karyotypes, and the patterns were different from those of the type strains of $L$. thermotolerans and L. waltii (Fig. 2). The results described above support the conclusion that strains $\mathrm{SC} 5 \mathrm{~L} 02^{\mathrm{T}}$, SC6L01 and ES12S06 represent a novel species closely related to $L$. thermotolerans and $L$. waltii.

\section{Taxonomy}

Strains SC5L02 ${ }^{\mathrm{T}}$, SC6L01 and ES12S06 exhibited similar physiological and morphological characteristics. They reproduce asexually by multilateral budding and sexually by producing one or two spherical ascospores per ascus after conjugation between individual cells (Fig. 3). The morphology of these strains does not allow them to be differentiated easily from other recognized species, whereas these strains can be distinguished from other Lachancea species in fermentation, assimilation reactions and cycloheximide resistance (Table 1). These strains can be 


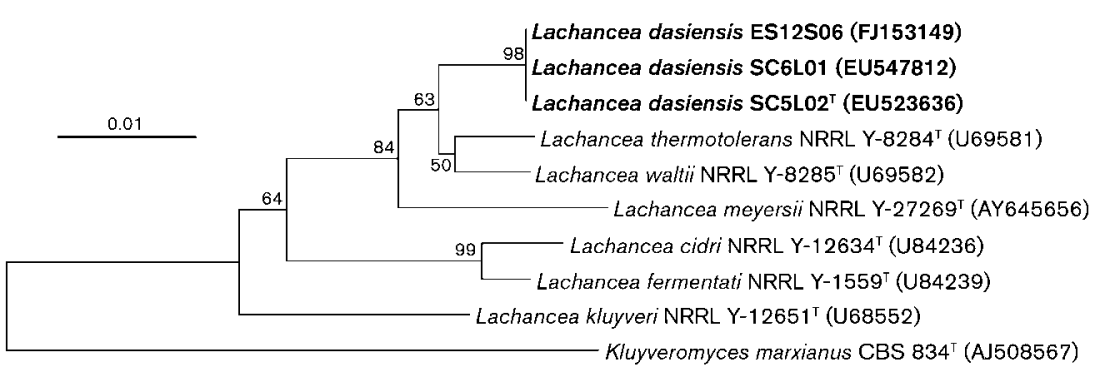

Fig. 1. Neighbour-joining phylogenetic tree, based on the sequence of the D1/D2 domain of the LSU rRNA gene, showing the relationships of strains of Lachancea dasiensis sp. nov. and related species of the Lachancea clade. Kluyveromyces marxianus CBS $834^{\top}$ was used as an outgroup. Bootstrap values of $50 \%$ or above are given at branch nodes and are based on 1000 replicates. All taxa are represented by type strains. Bar, 0.01 substitutions per nucleotide position. differentiated from $L$. thermotolerans in cycloheximide resistance and from $L$. waltii in the fermentation of $\mathrm{D}$ galactose and maltose and assimilation of many carbon compounds (Table 1). Based on the evidence described above, a novel species, Lachancea dasiensis sp. nov., is proposed to accommodate these strains.

\section{Latin diagnosis of Lachancea dasiensis Lee sp. nov.}

In medio liquido cum glucoso et peptono et extracto levidinis post dies 3 ad $25{ }^{\circ} \mathrm{C}$, cellulae ovoideae vel ellipsoideae (2.7$5.2 \times 3.0-6.3 \mu \mathrm{m})$, singulae aut binae, per gemmationem reproducentes. Post 1 mensem sedimentum formatur. Cultura in agaro cum glucoso et peptono et extracto levidinis post dies 7 ad $25{ }^{\circ} \mathrm{C}$, cremea, butyrosa, glabra et nitida. In agaro farinae Zea mays post dies 10 ad $25^{\circ} \mathrm{C}$, mycelium et

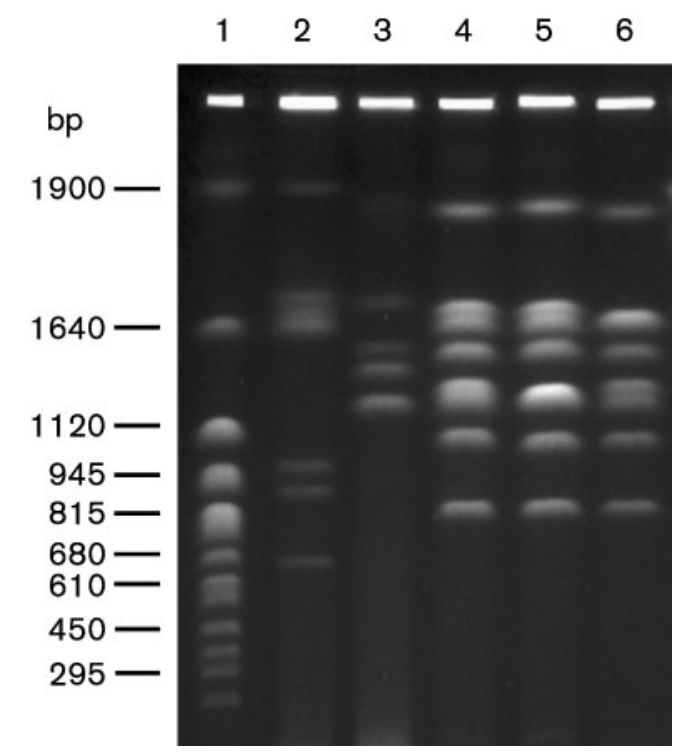

Fig. 2. Electrophoretic karyotypes of strains of $L$. dasiensis sp. nov. and related strains. Lanes: 1, Saccharomyces cerevisiae YPH80; 2, L. thermotolerans NRRL Y-8284 ${ }^{\top} ; 3$, L. waltii BCRC $22066^{\top} ; 4$, L. dasiensis SC5L02 ${ }^{\top} ; 5$, L. dasiensis SC6L01; 6, L. dasiensis ES12S06. pseudomycelium nulla. Asci formantur ex conjugatione inter cellulas. Asci continentes 1-2 ascosporas sphaericas (2.9$3.2 \mu \mathrm{m})$. Glucosum, galactosum, maltosum, methyl $\alpha$-Dglucosidum, sucrosum, melibiosum (infirme), melezitosum et raffinosum fermentantur, at non $\alpha, \alpha$-trehalosum, lactosum, cellobiosum, inulinum, amylum, nec D-xylosum. Glucosum, galactosum, sucrosum, maltosum, $\alpha, \alpha$-trehalosum (infirme), methyl $\alpha$-D-glucosidum, melibiosum, raffinosum, melezitosum, D-glucitolum, D-mannitolum, et D-glucono-1,5-lactonum assimilantur, at non L-sorbosum, D-glucosaminum, D-
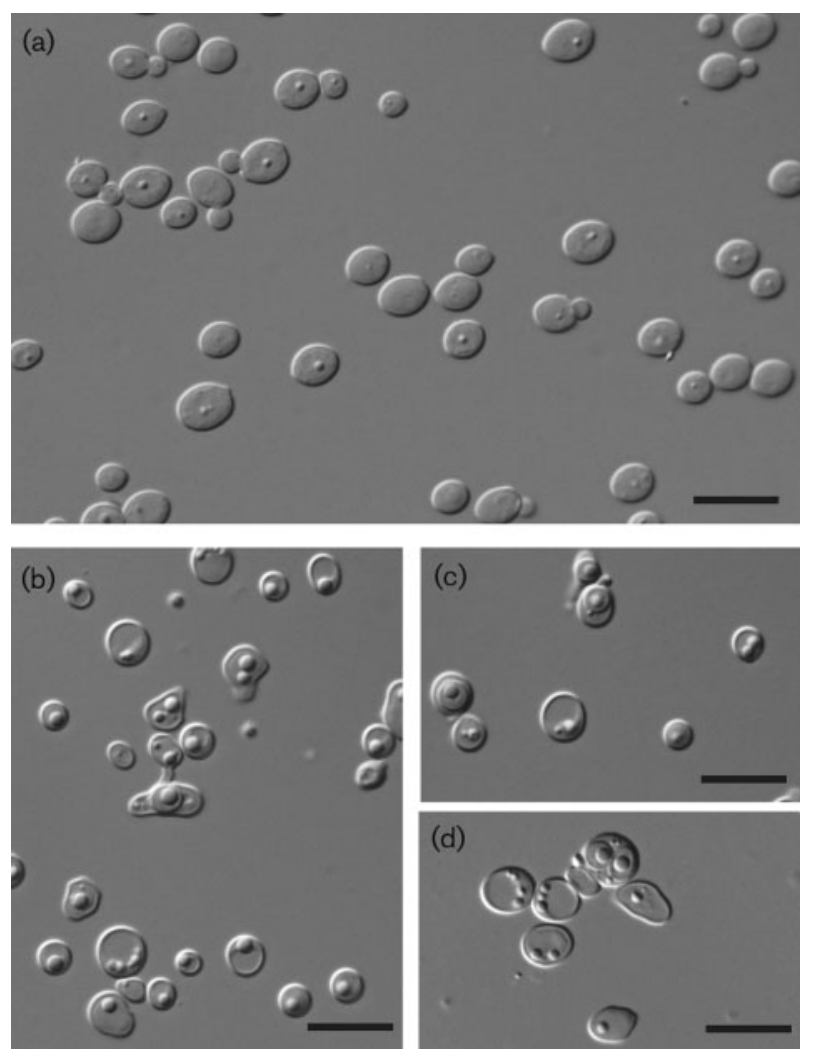

Fig. 3. Morphology of $L$. dasiensis SC5LO2 ${ }^{\top}$ as determined by light microscopy. (a) Budding cells of the strain in YM broth for 3 days at $25^{\circ} \mathrm{C}$. ( $\left.b-d\right)$ Ascospores produced on McClary's acetate agar after 28 days at $18^{\circ} \mathrm{C}$. Bars, $10 \mu \mathrm{m}$. 
Table 1. Comparison of phenotypic characteristics of $L$. dasiensis sp. nov. and other recognized species of the genus

Species: 1, L. dasiensis sp. nov. (data from this study); 2, $L$. thermotolerans (data from Lachance, 1998); 3, L. waltii (Lachance, 1998); 4, L. meyersii (Fell et al., 2004); 5, L. cidri (Vaughan-Martini \& Martini, 1998); 6, L. fermentati (Vaughan-Martini \& Martini, 1998); 7, L. kluyveri (Kurtzman, 1998). +, Positive; -, negative; w, weak; v, variable; D, delayed growth; s, slow growth.

\begin{tabular}{|lcccccccc|}
\hline Characteristic & $\mathbf{1}$ & $\mathbf{2}$ & $\mathbf{3}$ & $\mathbf{4}$ & $\mathbf{5}$ & $\mathbf{6}$ & $\mathbf{7}$ \\
\hline Fermentation of: & & & & & & & & \\
$\quad$ D-Galactose & + & $\mathrm{V}$ & - & - & + & + & + \\
Maltose & + & $\mathrm{V}$ & - & $\mathrm{V}$ & + & + & - \\
$\alpha, \alpha$-Trehalose & - & $\mathrm{S}$ & - & $\mathrm{W}$ & + & + & - \\
Melibiose & $\mathrm{W}$ & - & - & - & + & $\mathrm{V}$ & + \\
Assimilation of: & & & & & & & \\
D-Galactose & + & + & - & - & + & + & + \\
L-Sorbose & - & $\mathrm{V}$ & + & - & $\mathrm{S}$ & + & $\mathrm{V}$ \\
Maltose & + & + & - & + & + & + & + \\
$\alpha, \alpha$-Trehalose & $\mathrm{W}$ & + & - & + & + & + & + \\
Methyl $\alpha$-D-glucoside & + & + & - & + & + & + & + \\
Melibiose & + & $\mathrm{V}$ & - & - & + & $\mathrm{V}$ & + \\
Melezitose & + & + & - & + & - & + & $\mathrm{V}$ \\
Inulin & - & $\mathrm{V}$ & - & $\mathrm{V}$ & + & $\mathrm{V}$ & - \\
Glycerol & - & $\mathrm{V}$ & - & $\mathrm{D}$ & + & $\mathrm{V}$ & $\mathrm{V}$ \\
2-Keto-D-gluconate & - & $\mathrm{V}$ & - & + & + & + & - \\
DL-Lactate & - & - & - & - & + & + & + \\
Succinate & - & $\mathrm{V}$ & - & - & + & + & - \\
Ethanol & - & $\mathrm{S}$ & + & $\mathrm{D}$ & + & + & + \\
Growth with: & & & & & & & \\
$0.01 \%$ Cycloheximide & + & - & + & - & + & + & - \\
$10 \%$ NaCl & - & $\mathrm{V}$ & - & + & + & $\mathrm{V}$ & - \\
& & & & & & & & \\
\hline
\end{tabular}

ribosum, D-xylosum, L-arabinosum, D-arabinosum, L-rhamnosum, cellobiosum, salicinum, arbutinum, lactosum, inulinum, amylum, glycerolum, erythritolum, ribitolum, xylitolum, L-arabinitolum, galactitolum, myo-inositolum, acidum 2-keto-D-gluconicum, acidum 5-keto-D-gluconicum, acidum D-gluconicum, acidum D-glucuronicum, acidum Dgalacturonicum, acidum DL-lacticum, acidum succinicum, acidum citricum, methanolum, ethanolum, propane-1,2diolum, butane-2,3-diolum nec $N$-acetylglucosaminum. LLysinum et ethylaminum assimilatur, at non nitrosum, nitricum, creatinum, nec cadaverinum. Ad crescentiam vitamina externa necessaria sunt. Crescere potest in $50 \%$ glucosum et $0.1 \%$ cycloheximido. Non crescit in substrato $10 \%$ sal/ $5 \%$ glucosum continente. Non crescit in $60 \%$ glucosum addito. In $30{ }^{\circ} \mathrm{C}$ crescere potest at non in $35{ }^{\circ} \mathrm{C}$. Materia amyloidae iodophila non formatur. Ureum non hydrolysatur. Diazonium caeruleum B est negativum.

Typus stirpis SC5L02 ${ }^{\mathrm{T}}\left(=\mathrm{CBS} 10888^{\mathrm{T}}=\mathrm{BCRC} 23139^{\mathrm{T}}\right)$ isolatus ex folio, Dasi, Taoyuan, Taiwan. Bioresources Collection and Research Center (BCRC), Food Industry Research and Development Institute, Taiwan, et Centraalbureau voor Schimmelcultures (CBS), Utrecht, The Netherlands, deposita est.

\section{Description of Lachancea dasiensis Lee sp. nov.}

Lachancea dasiensis (da.si.en'sis. N.L. fem. adj. dasiensis pertaining to Dasi, Taoyuan, Taiwan, from where the yeast was originally isolated).

After growth in $\mathrm{YM}$ broth at $25^{\circ} \mathrm{C}$ for 3 days, cells are ovoidal to ellipsoidal, $2.7-5.2 \times 3.0-6.3 \mu \mathrm{m}$, and occur singly or in pairs (Fig. 3a). Vegetative reproduction is by multilateral budding. Sediment is present. After 7 days at $25{ }^{\circ} \mathrm{C}$ on YM agar, streak cultures are creamy, butyrous, smooth and glistening. On Dalmau plate cultures on cornmeal agar after 10 days at $25^{\circ} \mathrm{C}$, neither pseudomycelium nor true mycelium is formed under the cover glass. Sporulation occurs on McClary's acetate agar and V8 agar, but not on YM agar, malt agar or cornmeal agar after incubation at $18{ }^{\circ} \mathrm{C}$ for 28 days. Asci may result from conjugation between independent cells (Fig. 3b). Ascospores are spheroidal $(2.9-3.2 \mu \mathrm{m}$ in diameter) with one or two per ascus (Fig. 3c, d). Glucose, galactose, maltose, methyl $\alpha$-D-glucoside, sucrose, melibiose (weak), melezitose and raffinose are fermented, but $\alpha, \alpha$-trehalose, lactose, cellobiose, inulin, starch and D-xylose are not fermented. Glucose, galactose, sucrose, maltose, $\alpha, \alpha-$ trehalose (weak), methyl $\alpha$-D-glucoside, melibiose, raffinose, melezitose, D-glucitol, D-mannitol and D-glucono1,5-lactone are assimilated; L-sorbose, D-glucosamine, Dribose, D-xylose, L-arabinose, D-arabinose, L-rhamnose, cellobiose, salicin, arbutin, lactose, inulin, starch, glycerol, erythritol, ribitol, xylitol, L-arabinitol, galactitol, myoinositol, 2-keto-D-gluconate, 5-keto-D-gluconate, D-gluconate, D-glucuronate, D-galacturonic acid, DL-lactate, succinate, citrate, methanol, ethanol, propane-1,2-diol, butane-1,2-diol and $\mathrm{N}$-acetylglucosamine are not assimilated. Ethylamine and L-lysine are assimilated; nitrate, nitrite, creatine and cadaverine are not assimilated. Growth in vitamin-free medium is negative. Growth on $50 \%$ glucose is positive. Growth on $60 \%$ glucose and on $10 \%$ $\mathrm{NaCl}$ plus $5 \%$ glucose is negative. Growth occurs in the presence of $0.1 \%$ cycloheximide. Growth occurs at $30{ }^{\circ} \mathrm{C}$ but not at $35{ }^{\circ} \mathrm{C}$. No starch-like substance is produced. Acid production on chalk agar is negative. Urease hydrolysis and diazonium blue $\mathrm{B}$ reaction are negative.

The type strain, strain SC5L02 ${ }^{\mathrm{T}}\left(=\mathrm{CBS} 10888^{\mathrm{T}}=\mathrm{BCRC}\right.$ $23139^{\mathrm{T}}$ ), was isolated from a leaf of Angiopteris lygodiifolia Rosenst. in Dasi, Taoyuan, Taiwan, in 2006.

\section{Acknowledgements}

This work was supported by a Grant-in-Aid (NSC 96-2621-B-134001) from the National Science Council, Executive Yuan, Taiwan.

\section{References}

Barnett, J. A., Payne, R. W. \& Yarrow, D. (2000). Yeasts: Characteristics and Identification, 3rd edn. Cambridge: Cambridge University Press.

Carle, G. F. \& Olson, M. V. (1985). An electrophoretic karyotype for yeast. Proc Natl Acad Sci U S A 82, 3756-3760. 
Fell, J. W., Statzell-Tallman, A. \& Kurtzman, C. P. (2004). Lachancea meyersii sp. nov., an ascosporogenous yeast from mangrove regions in the Bahama Islands. Stud Mycol 50, 359-363.

Felsenstein, J. (1985). Confidence limits on phylogenies: an approach using the bootstrap. Evolution 39, 783-791.

Filipov, G. S. (1932). Porca fruktovyh konservov, vyzvannaja drozzevym gribkom. Tr Gent Nauchnoissled Bohim Inst Pisc Vkus Prom Narkomsnaba Sojuza SSR 2, 26-32 (in Russian).

Kodama, K. \& Kyono, T. (1974). Ascosporogenous yeasts isolated from tree exudates in Japan. J Ferment Technol 52, 1-9.

Kumar, S., Tamura, K. \& Nei, M. (2004). MEGA3: integrated software for molecular evolutionary genetics analysis and sequence alignment. Brief Bioinform 5, 150-163.

Kurtzman, C. P. (1998). Zygosaccharomyces Barker. In The Yeasts, a Taxonomic Study, 4th edn, pp. 424-436. Edited by C. P. Kurtzman \& J. W. Fell. Amsterdam: Elsevier.

Kurtzman, C. P. (2003). Phylogenetic circumscription of Saccharomyces, Kluyveromyces and other members of the Saccharomycetaceae, and the proposal of the new genera Lachancea, Nakaseomyces, Naumovia, Vanderwaltozyma and Zygotorulaspora. FEMS Yeast Res 4, 233-245.

Kurtzman, C. P. \& Robnett, C. J. (1998). Identification and phylogeny of ascomycetous yeasts from analysis of nuclear large subunit (26S) ribosomal DNA partial sequences. Antonie van Leeuwenhoek 73, 331371.

Kurtzman, C. P. \& Robnett, C. J. (2003). Phylogenetic relationships among yeasts of the 'Saccharomyces complex' determined from multigene sequence analyses. FEMS Yeast Res 3, 417-432.

Lachance, M. A. (1998). Kluyveromyces van der Walt emend. van der Walt. In The Yeasts, a Taxonomic Study, 4th edn, pp. 227-247. Edited by C. P. Kurtzman \& J. W. Fell. Amsterdam: Elsevier.
Lee, C. F., Liu, C. H., Young, S. S. \& Chang, K. S. (2008). Kazachstania jiainicus sp. nov., an ascomycetous yeast species isolated from soil in Taiwan. FEMS Yeast Res 8, 114-118.

Legakis, Ph. A. (1961). A contribution to the study of the yeast flora of apples and apple wine. Thesis, University of Athens, Greece.

Naganishi, H. (1928). The study of five new species of yeast. J Zymol 6, 1-12.

Naumova, E. S., Serpova, E. V. \& Naumov, G. I. (2007). Molecular systematics of Lachancea yeasts. Biochemistry (Mosc) 72, 1356-1362.

Phaff, H. J. \& Knapp, E. P. (1956). The taxonomy of yeasts found in exudates of certain trees and other natural breeding sites of some species of Drosophila. Antonie van Leeuwenhoek 22, 117-130.

Suzuki, M. \& Nakase, T. (2002). A phylogenetic study of ubiquinone7 species of the genus Candida based on $18 \mathrm{~S}$ ribosomal DNA sequence divergence. J Gen Appl Microbiol 48, 55-65.

Thompson, J. D., Gibson, T. J., Plewniak, F., Jeanmougin, F. \& Higgins, D. G. (1997). The CLUSTAL_X windows interface: flexible strategies for multiple sequence alignment aided by quality analysis tools. Nucleic Acids Res 25, 4876-4882.

Vaughan-Martini, A. \& Martini, A. (1998). Saccharomyces Meyen ex Rees. In The Yeasts, a Taxonomic Study, 4th edn, pp. 358-371. Edited by C. P. Kurtzman \& J. W. Fell. Amsterdam: Elsevier.

White, T. J., Bruns, T., Lee, S. \& Taylor, J. (1990). Amplification and direct sequencing of fungal ribosomal RNA genes for phylogenetics. In PCR Protocols: a Guide for Methods and Applications, pp. 315-322. Edited by M. A. Innis, D. H. Gelfand, J. J. Sninsky \& T. J. White. New York: Academic Press.

Yarrow, D. (1998). Methods for the isolation, maintenance and identification of yeasts. In The Yeasts, a Taxonomic Study, 4th edn, pp. 77-100. Edited by C. P. Kurtzman \& J. W. Fell. Amsterdam: Elsevier. 